\title{
Trends in Soil Quality Under High Tunnels
}

Sharon J.B. Knewtson and Rhonda Janke ${ }^{\mathbf{1}}$

Department of Horticulture, Forestry, and Recreation Resources, 2021 Throckmorton Plant Sciences Center, Kansas State University, Manhattan, KS 66506

M.B. Kirkham

Department of Agronomy, 2004 Throckmorton Plant Sciences Center, Kansas State University, Manhattan, KS 66506

Kimberly A. Williams and Edward E. Carey

Department of Horticulture, Forestry, and Recreation Resources, 2021 Throckmorton Plant Sciences Center, Kansas State University, Manhattan, KS 66506

Additional index words. hoophouse, particulate organic matter carbon, salinity, survey, total carbon

Abstract. Growers have indicated that changes in soil quality under production in high tunnels is an important problem, but these have not yet been quantified or critically assessed in the central Great Plains of the United States. We conducted surveys of grower perceptions of soil quality in their tunnels $(n=81)$ and compared selected soil quality indicators (salinity and particulate organic matter carbon) under high tunnels of varying ages with those of adjacent fields at sites in Kansas, Missouri, Nebraska, and Iowa in the United States. Fourteen percent of growers surveyed considered soil quality to be a problem in their high tunnels, and there were significant correlations between grower perceptions of soil quality problems and reported observations of clod formation and surface crusting and to a lesser extent surface mineral deposition. Grower perception of soil quality and grower observation of soil characteristics were not related to high tunnel age. Soil surface salinity was elevated in some high tunnels compared with adjacent fields but was not related to time under the high tunnel. In the soil upper $5 \mathrm{~cm}$, salinity in fields did not exceed $2 \mathrm{dS} \cdot \mathrm{m}^{-1}$ and was less than $2 \mathrm{dS} \cdot \mathrm{m}^{-1}$ under $74 \%$ of high tunnels and less than $4 \mathrm{dS} \cdot \mathrm{m}^{-1}$ in $\mathbf{9 7 \%}$ of high tunnels. The particulate organic matter carbon fraction was higher in high tunnels than adjacent fields at $73 \%$ of locations sampled. Particulate organic matter carbon measured 0.11 to $0.67 \mathrm{~g}$ particulate organic matter per $\mathrm{g}$ of the total carbon under high tunnels sampled. Particulate organic matter carbon in the soil was also not correlated to age of high tunnel. Soil quality as measured in this study was not negatively impacted by use of high tunnel structures over time.

In its simplest form, a high tunnel is clear plastic covering a frame high enough to walk inside, heated by solar radiation, and cooled by passive ventilation (Wells and Loy, 1993). Construction designs, materials, and other features vary. Producers use high tunnels to modify crop environment. The primary function is to elevate temperatures to allow earlier

Received for publication 21 July 2010. Accepted for publication 15 Aug. 2010.

Funding for this study was provided in part through a Sustainable Agriculture Research and Education graduate student grant to the senior author (project no. GNC05-048, Soil and Crop Quality under High Tunnels).

This manuscript is contribution number 10-065-J from the Kansas Agriculture Experiment Station, Manhattan, KS.

We thank the growers who allowed us to sample soils on their farms and who shared so generously their interests and insights about high tunnels.

${ }^{1}$ To whom reprint requests should be addressed; e-mail rjanke@ksu.edu. planting in the spring, earlier ripening, and extend fall harvests (Kadir et al., 2006; Lamont, 2005). Other benefits include wind and rain protection, reduction of some diseases and insects compared with the open field, and typically enhanced crop quality and yield (Lamont, 2005; Wells and Loy, 1993).

The number of vegetable, fruit, and flower growers using high tunnels in the central Great Plains has increased steadily in the past decade (Knewtson et al., 2010). These growers have expressed favorable high tunnel experiences, and there is continued interest in expanding production and improving high tunnel management (Knewtson et al., 2010). Variety and fertility trials in high tunnels in Kansas, Missouri, and Nebraska began in 2002 (Jett, 2004; Kadir et al., 2006; Zhao et al., 2007). However, the effect that cropping under high tunnels has on soil quality is unknown. High tunnel crops and soils are often more intensively managed than field crops, and the growing season is longer. Intensified production may increase soil nutrient removal, tillage, and traffic. There is concern that this combined with covering soil year round will result in a build up of insect pests, soil pathogens, and excess nutrient salt levels (Coleman, 1999). Strategies for soil revitalization have included soil sterilization, soil removal and replacement, removal of the plastic covering for part of the year, pesticide applications, and flushing irrigations (Coleman, 1999). Methods and frequency for physically moving high tunnels were discussed by Coleman (1999). Some growers have expressed concern that soil tilth seems to decline under high tunnels over time (Carey, unpublished data). However, a decline of soil quality has not been confirmed by research

One strategy to determine if high tunnels alter soil quality is to make paired comparisons of soils from individual high tunnels and adjacent fields. Comparison using high tunnels of varying age would allow evaluation of possible relationships between soil quality and the length of time that the soil was covered. Soil quality comparisons require appropriate indicators to quantify quality. Indicators may include measures of crop productivity or of chemical, physical, or biological soil qualities (Lal, 1994). The use of crop production indicators requires years of data (Dumanski and Pieri, 2000) and so is not useful as a survey tool.

Chemical indicators of soil quality include measurement of salinity. A combination of excessive fertilizer applications, irrigation, and poor drainage can induce salinity (Brady and Weil, 1999), so in some high tunnels, it may be advisable to monitor salinity. Nutrient analysis would not be useful in this study because of potential fertilizer application differences between a high tunnel and the field.

Soil organic matter (SOM) is a commonly used biological indicator of soil quality. Organic matter influences soil structure, nutrient storage, water-holding capacity, biological activity, tilth, water and air infiltration, erosion, and even efficacy of chemical amendments made to soil (Dumanski and Pieri, 2000). Particulate organic matter (POM) is labile organic matter of size fraction $53 \mu \mathrm{m}$ to $2 \mathrm{~mm}$, and it has the advantage as an indicator of soil quality of faster response to environmental change than SOM (Elliott et al., 1994; Wander, 2004). Changes in POM can be used to predict trends in SOM. Gregorich and Janzen (1996) cited four studies that showed greater resolution and sensitivity in measurements of POM change compared with SOM change. POM has been correlated to microbial biomass (Wander and Bidart, 2000), carbon and nitrogen mineralization (Bremer et al., 1994; Janzen et al., 1992), and soil aggregate formation and stability (Waters and Oades, 1991), demonstrating that increased POM indicates improved soil quality. Evaluation of the portion of the soil carbon in the POM size fraction can be used for comparison of locations or for comparison of changes over time.

The overall objective of the current study was to evaluate soil quality in high tunnels in the central Great Plains. Soil quality was 
assessed by grower perception and measures of the soil quality indicators of salinity and POM. To assess grower perception, we conducted a survey of producers and asked them about their soil conditions and management practices. We complemented the written questionnaire by sampling soil and comparing quality attributes of soils from established high tunnels and adjacent fields at the farms of survey respondents in four states.

\section{Materials and Methods}

Survey of high tunnel management and grower perception of soil quality. Growers with more than 2 years of experience with high tunnels were sought in Kansas, Missouri, Nebraska, and Iowa to gather information about grower perceptions of soil quality. A survey was offered online beginning June 2005 and removed in Oct. 2007 as a link from http://www.hightunnels.org, a web site maintained by Kansas State University. It was also offered in booklet format at the Great Plains Vegetable Growers Conference held in St. Joseph, MO, in Jan. 2006. Contact information of vegetable producers possibly using high tunnels was provided by research and extension agents in Iowa, Kansas, Missouri, and Nebraska and by other growers. The senior author traveled to visit growers who used high tunnels in the four-state region. The questionnaire was delivered during the visit if the grower had not already completed one either at the Great Plains Vegetable Growers Conference or online. Growers who did not return the questionnaire during the farm visit were given an addressed, stamped envelope for survey return. Details of the survey and an expanded report on survey questions, responses, and high tunnel management trends were summarized by Knewtson et al. (2010).

The survey consisted of 30 multiple-choice or fill-in-the-blank questions and six that invited description or discussion. The first five survey questions addressed demographics (high tunnel age, size, number, and crop history). The sixth question asked, "Are you experiencing soil quality problems in any of your high tunnels?" Response options were: yes, no, and not sure. Growers were classified as those who self-identified as having a soil quality problem and those who did not have a problem based on this question. The growers' opinions about high tunnel soil quality were thus gauged in general before they were asked about specific soil observations such as soil surface crusting, visible mineral deposits, clod, or hardpan formation. A response left blank or indicated as "not sure" was not included in the statistical analysis. Responses from the 81 surveys collected from the fourstate region of interest were compiled for this report.

Soil sample collection. Soil quality indicators were tested in 2005 under high tunnels erected in 2002 and in adjacent fields at the Kansas State University Research and Extension Center, Olathe, KS, and at the John C. Pair Horticultural Center, Haysville, KS (Knewtson, 2008). Soil was collected from at least five random spots within crop rows and then combined so that each high tunnel, or field plot, represented a sample. At the Olathe site, samples were collected from three organically managed and three conventionally managed high tunnels and the same number of matching adjacent field plots on a Kennebec silt loam (fine-silty, mixed, superactive, mesic Cumulic Hapludolls) soil that was formerly pasture. The Haysville site had four conventionally managed high tunnels and four matching plots adjacent on a Canadian-Waldeck sandy loam (coarse-loamy, mixed, superactive thermic Udic Haplustolls, and Fluvaquentic Haplustolls) soil that was formerly used for vegetable production. Based on the standard deviation of POM measurements in this preliminary work and using information from Ott and Longnecker (2001), we calculated that a sample size of 25 high tunnel and adjacent field pairs would be needed to measure a 5\% mean difference in POM ( $\alpha$ and $\beta=0.025$ ). Because farm sample variability would potentially be higher than at the research stations where high tunnels and adjacent field plots are managed with matching crop and fertility programs, our goal was to collect soil from double (greater than 50) the estimated sample size requirement (see "Indicators of Soil Quality" section).

Soil was collected from high tunnels and adjacent fields on farms in Kansas, Missouri, Nebraska, and Iowa in the fall of 2006 (Knewtson et al., 2010). Soil collection was focused on high tunnels that had been in place at least 3 years. The growers surveyed owned a total of 185 high tunnels. We collected more samples than what would later be used, collecting from 128 tunnels. Only nine high tunnels in use for less than 3 years were included in the soil collection. Soil was col- lected adjacent to the high tunnel for quality comparison. Management of the adjacent fields varied. Fields were cultivated with horticultural crops, pasture, or ornamental turf. If there was a similarly managed area (e.g., vegetable crops) near the high tunnel, this was sampled rather than a grassy area. Locations where soil under the high tunnel was not that of the adjacent field (e.g., creek bottom soil had been brought into the high tunnel) were not included in the data set.

Soil samples representing a high tunnel or field were a combination of at least five random collections within crop rows. Soil was collected with a trowel from the surface $5 \mathrm{~cm}$ for salinity analysis. Soil particulate organic matter carbon, total carbon, and salinity were determined in soil collected to the $15-\mathrm{cm}$ depth with a soil probe. Surface salinity measurements for locations recently tilled were not included in this data set.

Indicators of soil quality. Salinity was measured as electrical conductivity (EC) in water extracted from a 1:2 soil and water slurry (Rhoades, 1996). Salinity is reported from 93 high tunnels on 63 farms.

Total soil carbon was measured in soil samples ground with a mortar and pestle and then combusted (TruSpec CN 2000; Leco Corp., St. Joseph, MI). The POM fraction was separated by moist sieving soil samples that were dispersed in $0.5 \%$ sodium hexametaphosphate through a $53-\mu \mathrm{m}$ sieve (Gregorich and Ellert, 1993). Sieves were rinsed with distilled water so clay and silt size particles drained out. Sand and POM retained on the sieve were dried at $55{ }^{\circ} \mathrm{C}$ and ground with a mortar and pestle. Carbon was measured in POM by combustion (TruSpec CN 2000). Total soil carbon and POM carbon are reported from 80 high tunnels on 53 farms.

Statistical analysis of soil quality and management factors. Statistical analysis of the effect of high tunnel presence on measures of soil quality was done using the general linear model procedure (SAS 9.1; Statistical Analysis System Institute, Cary, NC) and comparison of least square means. Results were analyzed for correlations between the quantified soil quality indicators and the following: observations of soil conditions as reported for that location in the grower questionnaire and tunnel age. Statistical tests included $t$ tests with binomial data, $\chi^{2}$ tests of independence with categorical data, and correlations with numeric data.

Table 1. Grower perception of soil quality and specific soil characteristics observed by growers as reported in a survey of 81 high tunnel producers from Iowa, Kansas, Missouri, and Nebraska.

\begin{tabular}{|c|c|c|c|c|c|c|c|c|c|}
\hline \multirow[b]{2}{*}{ Characteristic } & \multicolumn{8}{|c|}{ Perception of soil quality } & $\begin{array}{c}\begin{array}{c}\text { Total } \\
\text { responses }\end{array} \\
(\mathrm{n}=76)^{\mathrm{z}}\end{array}$ \\
\hline & Observed & Not observed & Observed & Not observed & Observed & Not observed & Observed & Not observed & \\
\hline Clod formation & 4 & 7 & 0 & 41 & 4 & 19 & 2 & 0 & $\mathrm{n}=77$ \\
\hline Surface crust & 4 & 7 & 2 & 39 & 5 & 17 & 1 & 1 & $\mathrm{n}=76$ \\
\hline Mineral deposition & 8 & 3 & 11 & 30 & 4 & 19 & 1 & 0 & $\mathrm{n}=76$ \\
\hline
\end{tabular}

${ }^{2}$ Some questionnaire participants did not choose to respond to all questions.

${ }^{\mathrm{y}}$ Grower may not have responded to soil quality problem query but later indicated observation of a soil characteristic. 


\section{Results and Discussion}

Grower perception of soil quality. Fourteen percent of survey respondents were of the opinion that they had soil quality problems in their high tunnels compared with adjacent fields (Table 1). Fifty-four percent of the 76 survey participants who responded to the soil quality problem question did not perceive problems. The remainder was uncertain if they had experienced soil quality problems.

Observation of adverse soil characteristics did not always cause a farmer to perceive a soil quality problem (Table 1). Clod formation was reported to be worse in high tunnels compared with outside by 10 growers, which is $13 \%$ of respondents to that question [i.e., $(4+0+4+2) / 77=0.13$; Table 1]. Surface crusting was observed by $16 \%$ of respondents and mineral surface deposits in $32 \%$ of high tunnels (Table 1). Hardpans were reported by $25 \%$ of respondents [i.e., $(5+9+4+0) / 73=$ 0.25 ; Table 1]. However, growers who selfidentified as having soil quality problems in high tunnels were more likely to report clod formation $(P=0.0001)$, surface crusting $(P=$ $0.0001)$, and surface mineral deposits $(P=$ $0.031)$ than those who did not (Table 2). Hardpan formation was less strongly correlated to perception of soil quality $(P=0.12)$.

When grower perception was compared with quantified measures of soil quality, we did not find a strong correlation. Grower perception of soil quality was not correlated to measures of soil salinity $(P=0.086)$, POM as a fraction of total carbon under the high tunnel $(P=0.23)$, or POM carbon under the high tunnel in ratio to the adjacent field $(P=$ 0.45).

Salinity. Mineral surface deposits reported by growers could potentially indicate salt accumulation near the soil surface. To verify salinity, we measured EC in the upper $5 \mathrm{~cm}$ of soil in high tunnels and adjacent fields and in the 0 to $15-\mathrm{cm}$ depth in select high tunnels. Soil with EC greater than $4 \mathrm{dS} \cdot \mathrm{m}^{-1}$ is considered saline (Brady and Weil, 1999). The highest EC measured in field soil was $2 \mathrm{dS} \cdot \mathrm{m}^{-1}$ and most were below $1 \mathrm{dS} \cdot \mathrm{m}^{-1}$ (Fig. 1A). From this it can be concluded that soils at the farms evaluated were not inherently saline.

Analysis did show salt accumulation in the surface $5 \mathrm{~cm}$ of some high tunnels; $25 \%$ had an EC of $2 \mathrm{dS} \cdot \mathrm{m}^{-1}$ or greater, and $3 \%$ had an EC greater than $4 \mathrm{dS} \cdot \mathrm{m}^{-1}$ in the upper $5 \mathrm{~cm}$ (Fig. 1B). A second set of salinity measurements was done on soil collected to a $15-\mathrm{cm}$ depth in 23 high tunnels with a surface EC of $2 \mathrm{dS} \cdot \mathrm{m}^{-1}$ or more (Fig. 1C). Only four had an EC greater than $2 \mathrm{dS} \cdot \mathrm{m}^{-1}$ in the upper $15 \mathrm{~cm}$ (Fig. 1C). The salinity problem of $3 \%$ of growers could have been caused by mineral build up from sources such as fertilizer, manure, compost, or irrigation water with elevated salts.

Surface salinity accumulation is potentially deleterious to seed germination or transplanted seedlings. A 10\% yield reduction may occur in tomato crops with soil EC $4 \mathrm{dS} \cdot \mathrm{m}^{-1}$ and in lettuce at $2 \mathrm{dS} \cdot \mathrm{m}^{-1}$ (Bernstein, 1964).

Table 2. Observed significance level (indicated by $P$ values) of correlations between soil quality indicators and high tunnel age as well as grower observations of soil. ${ }^{z}$

\begin{tabular}{lcccr}
\hline & \multicolumn{4}{c}{ Measure of soil quality } \\
\cline { 2 - 5 } & $\begin{array}{c}\text { Negative perception of } \\
\text { soil quality }\end{array}$ & Salinity & $\begin{array}{c}\text { POM in } \\
\text { HT }\end{array}$ & $\begin{array}{c}\text { POM } \\
\text { HT:Field }\end{array}$ \\
\cline { 2 - 5 } & 0.26 & $P$ value $^{\mathrm{w}}$ & 0.33 \\
\hline Age of high tunnel & & 0.96 & 0.61 \\
Soil observation & 0.0001 & 0.11 & 0.64 & 0.16 \\
Clod formation & 0.0001 & 0.18 & 0.30 & 0.34 \\
Surface crust & 0.031 & 0.34 & 0.46 & 0.69 \\
Mineral deposition & 0.12 & 0.71 & 0.044 & 0.21 \\
Hardpan & & & \\
\hline
\end{tabular}

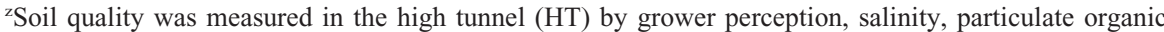
matter carbon as a fraction of total carbon in the high tunnel (POM in HT), and the ratio of particulate organic matter carbon in the high tunnel compared with the adjacent field (POM HT:Field).

${ }^{\mathrm{y}}$ Indicated by grower in a questionnaire.

${ }^{\mathrm{x}}$ Chi square test may not be valid because of low counts (less than five) in a category.

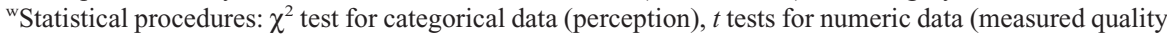
indicators) and a binomial factor (observation).
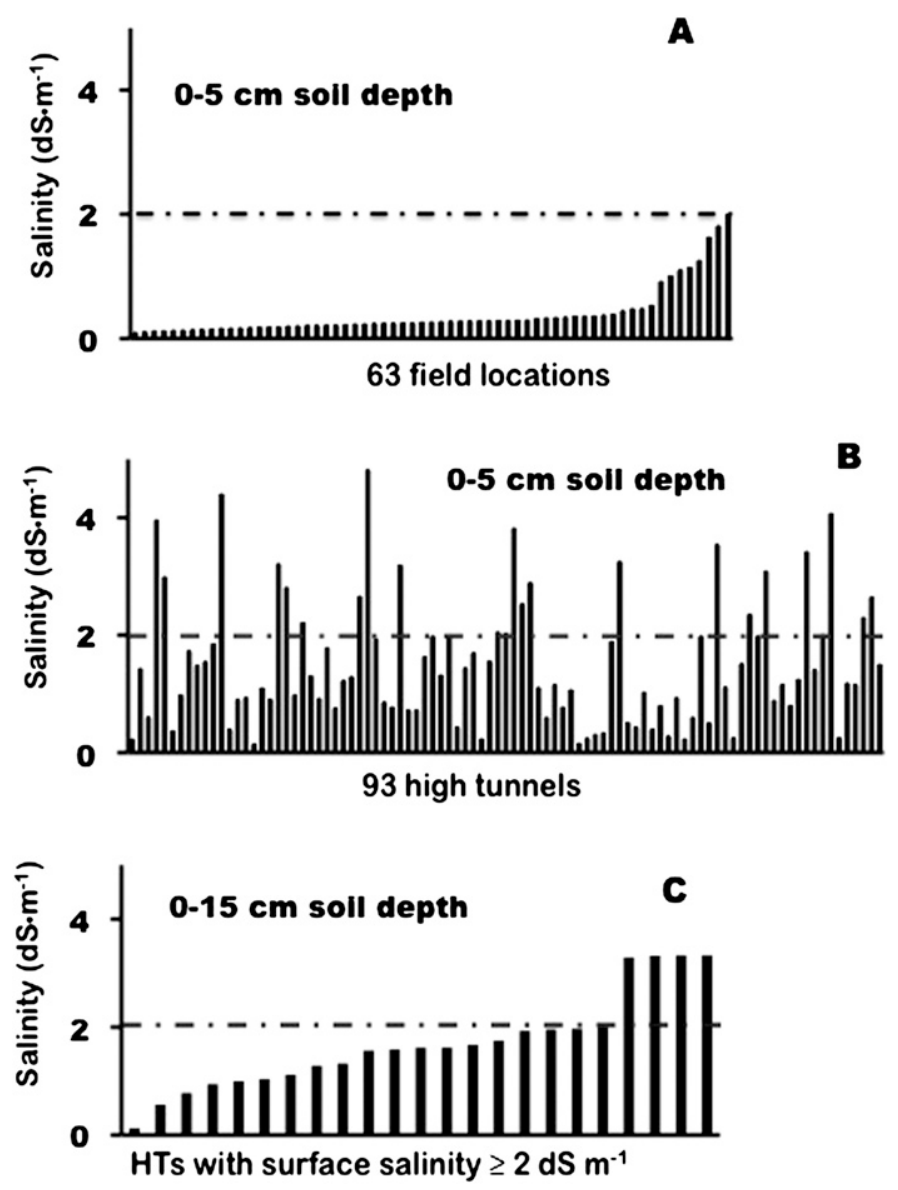

Fig. 1. Salinity in the surface upper $5 \mathrm{~cm}$ at (A) 63 field locations adjacent to high tunnels and (B) 93 high tunnels in the central Great Plains arranged from newest to oldest from left to right; and (C) salinity in the soil upper $15 \mathrm{~cm}$ in the high tunnels with salinity exceeding $2 \mathrm{dS} \cdot \mathrm{m}^{-1}$ in the upper $5 \mathrm{~cm}$.

The mean EC in the soil upper $5 \mathrm{~cm}$ was $1.5 \mathrm{dS} \cdot \mathrm{m}^{-1}$ in high tunnels and $0.40 \mathrm{dS} \cdot \mathrm{m}^{-1}$ in adjacent fields. Although salinity was higher in high tunnels than adjacent fields $(P=0.0001)$ indicating a potential for salt accumulation in high tunnels, accumulation was slight and mostly superficial. Most growers in this study could probably avoid yield reduction in high tunnels by leaching salts deeper into the soil profile with heavy irrigation before planting.

Based on these results, the surface mineral deposits reported by $32 \%$ of the survey re- spondents were not a cause for alarm. EC was not different $(P=0.34)$ in high tunnels with and without reported visible surface minerals (Table 2). The mineral deposition at the surface could be carbonates or salts. However, because both $\mathrm{pH}$ (Knewtson, 2008) and salinity were within acceptable limits at nearly all locations, the presence of a surface mineral deposit did not indicate a widespread soil quality problem under high tunnels.

Particulate organic matter carbon. In preliminary studies, POM measured as a fraction 
of total soil carbon (POM carbon $\div$ total soil carbon $=$ POM $\mathrm{TC}^{-1}$ ) was found to be different between high tunnel and field soils. Analysis of soil under 3-year-old research high tunnels and matching plots in the adjacent field at Olathe, KS, and Haysville, KS, revealed that POM $\mathrm{TC}^{-1}$ was higher under high tunnels than in the adjacent fields in organically managed plots at Olathe $(P<$ $0.0001)$ and conventionally managed plots at Haysville $(P=0.012)$ (Knewtson, 2008). It was also found that POM TC ${ }^{-1}$ was higher in organically compared with conventionally managed high tunnels at Olathe. From these initial tests we considered POM TC ${ }^{-1}$ to have good potential for this study as a quantifier of differences in soil quality.

Many growers give high tunnels priority when applying organic soil amendments, so that much of the organic matter in high tunnels may be fresher or less decomposed. In the survey, $85 \%$ of growers reported the use of organic amendments in their high tunnels (Knewtson et al., 2010). This was also evidenced in analysis of total soil carbon in that $70 \%$ of high tunnels were found to have higher total carbon than their adjacent field with $16 \%$ having double the amount of carbon. Total carbon under high tunnels ranged from 12 to $125 \mathrm{~g} \mathrm{C} / \mathrm{kg}$ soil and in adjacent fields from 11 to $96 \mathrm{~g} \mathrm{C} / \mathrm{kg}$ soil (Fig. 2 ). Soil carbon does not typically exceed $40 \mathrm{~g} \mathrm{C} / \mathrm{kg}$ soil (4\% of soil mass) in a Mollisol or Alfisol (Brady and Weil, 1999). Total soil carbon was higher than this in $25 \%$ of the high tunnels, but only in $6 \%$ of the fields sampled.

POM carbon as a fraction of total carbon ranged from 0.11 to $0.67 \mathrm{~g} \mathrm{POM} \mathrm{C/g} \mathrm{TC}$ under high tunnels (Fig. 3). In the fields, the

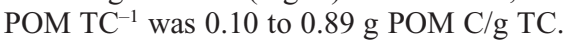
In other studies, POM was observed to make up $10 \%$ of total soil carbon $(0.10 \mathrm{~g}$ POM C/g TC) in long-term arable soil and $0.4 \mathrm{~g}$ POM $\mathrm{C} / \mathrm{g}$ TC under grassland (Christensen, 1996). POM carbon exceeded $0.4 \mathrm{~g}$ POM C/g TC in $26 \%$ of high tunnels and $9 \%$ of the fields adjacent to high tunnels. It exceeded $0.25 \mathrm{~g}$ $\mathrm{POM} \mathrm{C/g} \mathrm{TC} \mathrm{in} 78 \%$ of high tunnels compared with $48 \%$ of adjacent fields. High tunnel POM $\mathrm{TC}^{-1}$ tended to exceed that in adjacent fields $(P=0.0005)$, possibly indicating better soil quality under high tunnels. Seventy-three percent of high tunnels had POM TC ${ }^{-1}$ in excess of the adjacent field (Fig. 3), indicating that SOM under high tunnels tends to be less decomposed than in open fields.

Grower observations of soil clods, surface crusting, and mineral deposits were not well correlated to POM TC ${ }^{-1}$ in their high tunnels (Table 2). There was possibly a connection between POM $\mathrm{TC}^{-1}$ and perceived hardpan formation in high tunnels $(P=0.044)$, but the nature of this relationship is uncertain. Growers reporting hardpan formation had a higher mean POM TC ${ }^{-1}(0.39 \mathrm{~g} \mathrm{POM} / \mathrm{g}$ total C) compared with those not reporting hard pans $(0.31 \mathrm{~g} \mathrm{POM} / \mathrm{g}$ total $\mathrm{C})$. Higher POM $\mathrm{TC}^{-1}$ is usually associated with ease of tillage and enhanced infiltration (Brady and Weil, 1999), not pan formation.
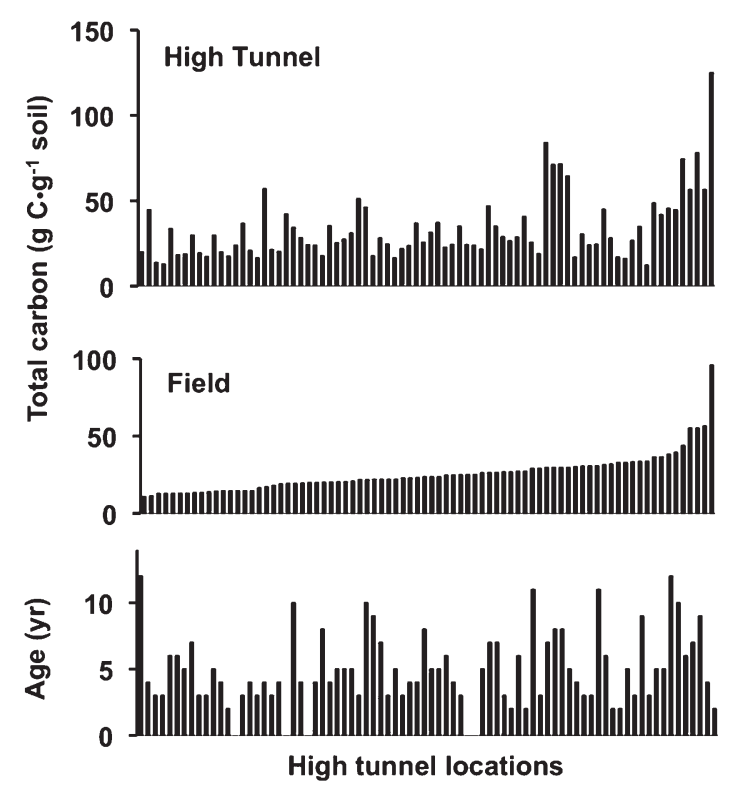

Fig. 2. Total soil carbon under high tunnels and in adjacent fields and, when known, age of the high tunnel in 2006 over matching $\mathrm{x}$-axes indicating 80 locations.
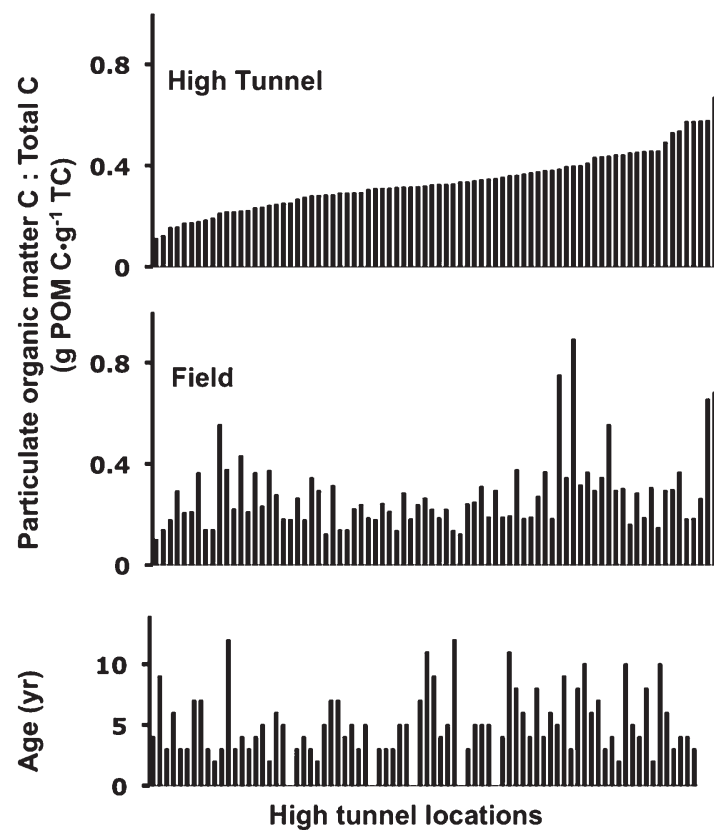

Fig. 3. Particulate organic matter carbon as a fraction of total soil carbon in high tunnel and field and, when known the age of the high tunnel in 2006 with matching x-axes indicating 80 locations on 53 farms.

To evaluate soil quality across locations, the relationship between high tunnel and field was considered. The high tunnel-to-adjacentfield ratio of the POM TC ${ }^{-1}$ fraction (POM HT:Field) ranged from 1:2.6 (or 0.38 ) to 1:0.32 (or 3.2). Grower observations of soil characteristics were not indicative of soil quality as measured by POM HT:Field. Observations of soil clods, surface crusts, surface mineral deposits, or hardpan formation were not correlated to POM HT:Field (Table 2). Also, the POM HT:Field ratio did not differ between growers who did and did not consider their high tunnel to have soil quality problems $(P=0.45)$.

High tunnel age effect on soil quality. The ages of high tunnels sampled on farms ranged from 1 to 15 years. The median high tunnel age was 5 years. Grower perception of soil quality did not differ with age of high tunnel $(P=0.26)$ (Table 2$)$. Growers with tunnels in situ for 2 to 15 years reported good soil quality $(n=41)$. Growers who reported soil quality problems had tunnels ranging in age from 3 to 11 years. Observations of negative soil attributes (surface clod, crust formation, and hardpan presence) were not related to time under a high tunnel (statistical data not shown).

Measured indicators of soil quality were also not correlated to the age of high tunnels (Table 2). Salinity was not significantly correlated to high tunnel age $(P=0.96)$. The POM $\mathrm{TC}^{-1}$ in high tunnels was also poorly 
correlated to tunnel age $(P=0.61)$. The portion of soil carbon made up by the POM fraction differed between the high tunnel and the adjacent field, but this difference was not because of the length of time a high tunnel covered the soil, as indicated by the lack of correlation between POM HT:Field and tunnel age $(P=0.33)$.

\section{Summary}

Fourteen percent of growers were of the opinion that soil quality was a problem in their high tunnel, whereas $54 \%$ did not perceive a problem, and $32 \%$ were uncertain. We found that salinity in the soil upper $15 \mathrm{~cm}$ was less than $2 \mathrm{dS} \cdot \mathrm{m}^{-1}$ in $95 \%$ of high tunnels sampled and in the soil upper $5 \mathrm{~cm}$ was less than $2 \mathrm{dS} \cdot \mathrm{m}^{-1}$ under $74 \%$ of high tunnels sampled and surface salinity was not related to time under the tunnel. Therefore, although salinity can become a problem in high tunnels, it was manageable in the geographic region of our study. POM carbon was 0.10 to $0.67 \mathrm{~g} \mathrm{POM} / \mathrm{g}$ TC under high tunnels sampled and indicated good soil quality. The POM carbon fraction was higher in high tunnels than in adjacent fields at $73 \%$ of locations sampled. Soil quality as measured by grower perception, salinity, and POM carbon as a fraction of total carbon did not correlate to high tunnel age and so could not be said to be negatively impacted by high tunnel structures over time. We conclude that soil quality can be successfully managed in high tunnels on the central Great Plains.

\section{Literature Cited}

Bernstein, L. 1964. Salt tolerance of plants. Agriculture Information Bulletin No. 283. U.S. Department of Agriculture, Washington, DC.

Brady, N.C. and R.R. Weil. 1999. The nature and properties of soils. Prentice-Hall, Inc., Upper Saddle River, NJ.
Bremer, E., H.H. Janzen, and A.M. Johnston. 1994. Sensitivity of total, light fractions and mineralizable organic matter to management practices in a Lethbridge soil. Can. J. Soil Sci. 74: 131-138.

Christensen, B.T. 1996. Carbon in primary and secondary organomineral complexes, p. 97165. In: Carter, M.R. and B.A. Stewart (eds.) Structure and organic matter storage in agricultural soils. Adv. Soil Sci. CRC Press, Inc., Boca Raton, FL.

Coleman, E. 1999. Four-season harvest: How to harvest fresh organic vegetables from your home garden all year long. Chelsea Green Publ. Co., White River Junction, VT.

Dumanski, J. and C. Pieri. 2000. Land quality indicators: Research plan. Agr. Ecosyst. Environ. 81:93-102.

Elliott, E.T., I.C. Burke, C.A. Monz, S.D. Frey, K.H. Paustian, H.P. Collins, E.A. Paul, C.V. Cole, R.L. Blevins, W.W. Frye, D.J. Lyon, A.D. Halvorson, D.R. Huggins, R.F. Turco, and M.V. Hickman. 1994. Terrestrial carbon pools: Preliminary data from the Corn Belt and Great Plains regions, p. 179-191. In: Doran, J.W., D.C. Coleman, D.F. Bezdicek, and B.A. Stewart (eds.). Defining soil quality for a sustainable environment. Soil Sci. Soc. Amer., Madison, WI.

Gregorich, E.G. and B.H. Ellert. 1993. Light fraction and macroorganic matter in mineral soils, p. 397-407. In: Carter, M.R. (ed.). Soil sampling and methods of analysis. Lewis Publishers, CRC Press Inc., Boca Raton, FL.

Gregorich, E.G. and H.H. Janzen. 1996. Storage of soil carbon in the light fraction and macroorganic matter, p. 167-190. In: Carter, M.R. and B.A. Stewart (eds.). Structure and organic matter storage in agricultural soils. Adv. Soil Sci. CRC Press, Inc., Boca Raton, FL.

Janzen, H.H., C.A. Campbell, S.A. Brandt, G.P Lafond, and L. Townley-Smith. 1992. Lightfraction organic matter in soils from long-term crop rotations. Soil Sci. Soc. Amer. J. 56:17991806.

Jett, L.W. 2004. Production of tomatoes within a high tunnel. Small Farm Today 21:36-40.

Kadir, S., E. Carey, and S. Ennahli. 2006. Influence of high tunnel and field conditions on straw- berry growth and development. HortScience 41 : 329-335.

Knewtson, S.J.B. 2008. Studies in vegetable and high tunnel production on the central Great Plains. PhD diss., Kansas State Univ., Manhattan, KS. Abstr. 2097/926.

Knewtson, S.J.B., E.E. Carey, and M.B. Kirkham. 2010. Management practices of growers using high tunnels in the central Great Plains of the United States. HortTechnology 20:639-645.

Lal, R. 1994. Methods and guidelines for assessing sustainable use of soil and water resources in the tropics. SMSS Tech. Bull. 21. USDA Soil Conservation Service, Washington, DC.

Lamont, W.J., Jr. 2005. Plastics: Modifying the microclimate for the production of vegetable crops. HortTechnology 15:477-481.

Ott, R.L. and M. Longnecker. 2001. An introduction to statistical methods and data analysis. 5th Ed. Duxbury, Pacific Grove, CA.

Rhoades, J.D. 1996. Salinity: Electrical conductivity and total dissolved solids, p. 417-435. In: Bigham, J.M., et al. (eds.). Methods of soil analysis. Part 3. Chemical methods., Soil Sci. Soc. Amer. and Amer. Soc. Agron., Madison, WI.

Wander, M. 2004. Soil organic matter fractions and their relevance to soil function, p. 68-102. In: Magdoff, F. and R.R. Weil (eds.). Soil organic matter in sustainable agriculture. CRC Press, Boca Raton, FL.

Wander, M.M. and M.G. Bidart. 2000. Tillage practice influences on the physical protection, bioavailability and composition of particulate organic matter. Biol. Fertil. Soils 32:360-367.

Waters, A.G. and J.M. Oades. 1991. Organic matter in water stable aggregates, p. 163-174. In: Wilson, W.S. (ed.). Advances in soil organic matter research: The impacts on agriculture and the environment. Royal Soc. Chem., Melksham, UK.

Wells, O.S. and J.B. Loy. 1993. Rowcovers and high tunnels enhance crop production in the northeastern United States. HortTechnology 3: 92-95.

Zhao, X., E.E. Carey, J.E. Young, W.Q. Wang, and T. Iwamoto. 2007. Influences of organic fertilization, high tunnel environment, and postharvest storage on phenolic compounds in lettuce. HortScience 42:71-76. 